\title{
A Cambodian Dancer in a Displaced Persons' Camp
}

\section{Toni Shapiro-Phim}

International Center for Ethics, Justice and Public Life, Brandeis University, Waltham, USA Correspondence: tonishapiro@brandeis.edu

\begin{abstract}
The more than a quarter of a million Cambodians in camps on the Thai side of the CambodiaThailand border in the late 20th century are referred to, in Khmer, as chun pies khluon. This translates into English as "refugees," but means, literally, "those who are escaping" or "people on the run." Existing between a then-recent past of devastating loss and a future as yet unknown, they remained in an unsettled situation of physical precarity for more than a decade as many of the camps along that border were in an active war zone.

Focusing mainly on one dancer in Site 2 camp, this essay explores ways in which dancers and musicians were bringing into being an aesthetic and spiritual potency that transcended the surrounding reality, not only as momentary escape, (though that can be powerful in its own right), but also as fortification against dehumanization. The combination of an embodied passing on of cultural knowledge with formal documentation of the arts and associated rituals reveal an eye to and imagination of a future back inside Cambodia, something at odds with the reality of the camp inhabitants' prolonged exile.
\end{abstract}

\section{Khmer Abstract}

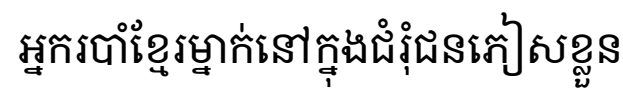

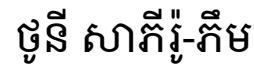

โธิษกีกธนผุ้บ

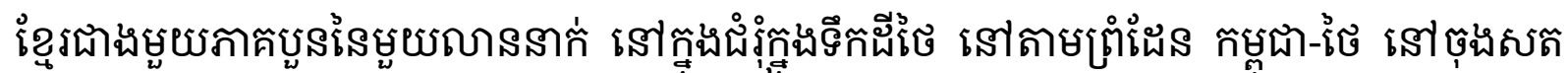

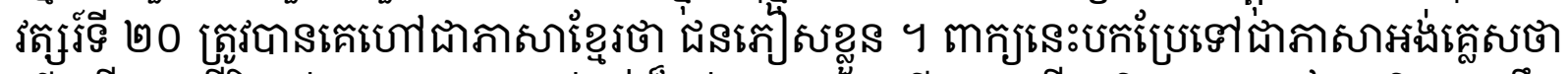

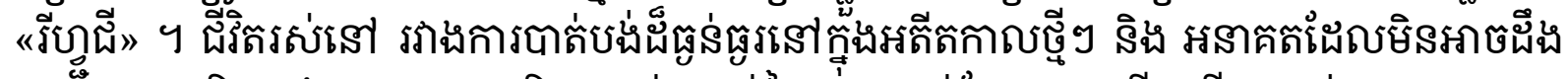

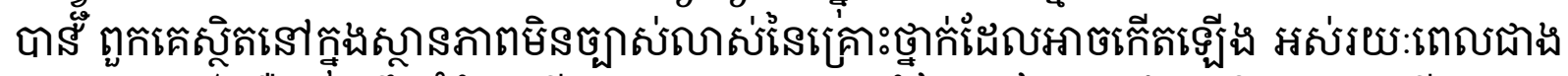

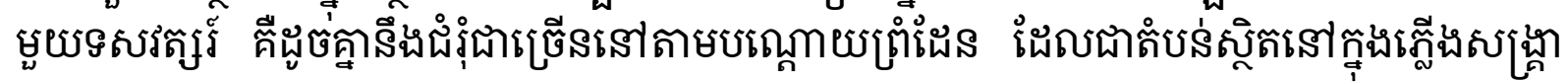
EY

This paper is published under a Creative Commons Attribution-NonCommercial 4.0 International License. To read the license text, visit https://creativecommons.org/licenses/by-nc/4.0/. Parts of an article may be published under a different license. If this is the case, these parts are clearly marked as such. 


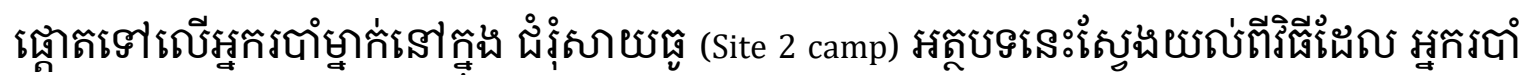

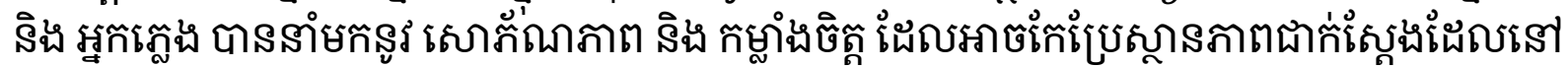

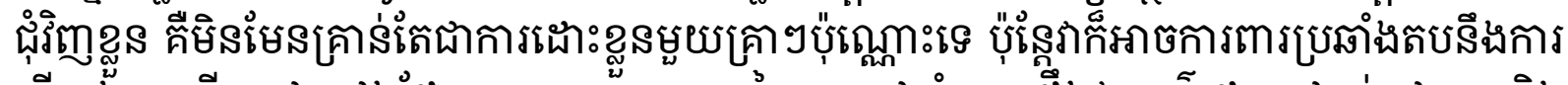

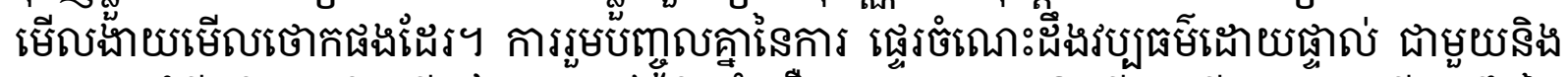

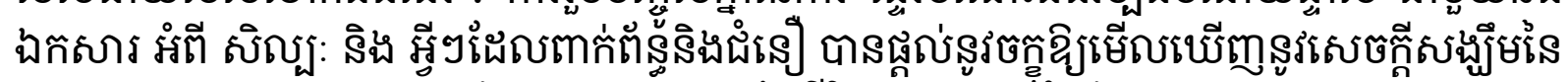

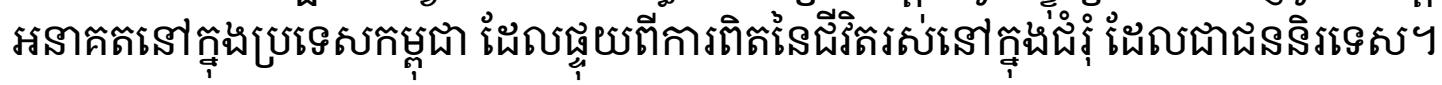

Translation from English to Khmer by Thavro Phim.

"The Wind Blowing"
My mind is as the wind blowing
No one can see and catch the wind
They are aware when the leaves fall and the top
of the trees shake...
There is a strong wind. The tree which has not
enough roots to support it will fall down
The tree is always steady when there is no wind.
- Socheata Men, resident of Site 2 Displaced Persons' camp ${ }^{1}$

On the occasion of World Refugee Day in June 2021, the United Nations High Commissioner for Refugees (UNHCR) noted that more than 80 million people "have been forced to flee war, conflicts and persecution and rebuild their lives far from home" (UNHCR 2021). Behind this number is the stark and devastating reality of existence for people in these unstable, unsafe and untenable situations, including those who are displaced for a protracted period of time, in some cases, a generation or longer. The UNHCR defines a "protracted" refugee situation as one "in which at least 25,000 from the same country have been living in exile for more than five consecutive years" (UNHCR 2020) in a given different country. Many in such circumstances are "deprived of freedom of movement, access to land, and legal employment. UNHCR estimates that the average length of major protracted refugee situations is now 26 years” (U.S. Department of State n.d.).

This essay uncovers stories of a dancer who spent more than a decade in exile in camps for the displaced on the Thai-Cambodian border in the 1980s when war raged between several political factions and the Vietnamese-backed regime then in control of Cambodia. Voan Savay, a renowned performing artist from Cambodia, turned a vast space of barrenness, deprivation, cruelty and uncertainty - a camp for displaced Cambodians - into a field of soil rich with treasured heritage, splendor, focus and imagined possibilities for the future. I've elected to place a spotlight on Voan Savay - her choices, her reflections - as a way to both honor the full complexity of lives lived in circumstances of dispossession and danger, and to draw attention to the crisis of prolonged exile, especially in camps where scarcity, violence and proscription reign.

\footnotetext{
${ }^{1}$ Socheata Men wrote this poem for an English-language class in Site 2, a camp for displaced Cambodians. This and other student poems are included in an essay by the teacher of that class, Ashley Thompson (1993).
} 


\section{The Dance}

$\mathrm{Khmer}^{2}$ classical dance... was developed as a prayer in movement for rain and fertility, and ... prosperity that this meant for an agricultural society. Dancers ... served as living bridges between heaven and earth. Their dancing bodies carried the prayers of the people up to the gods, and the will of the deities was delivered back through them (Ok 2017).

Classical dance in Cambodia, also referred to as the drama of the king or court dance, has a long history, its threads interwoven through the centuries with spiritual practices and beliefs related to animism, Brahmanism/Hinduism and Buddhism, ${ }^{3}$ and with royal rituals. Seventh-century inscriptions on stone temples tell of dancers associated with those hallowed places. Until the 1970 coup d'état that sent the royal family into exile, sacred dances and musical pieces were performed under the auspices of the king and queen to ask for blessings for the land and the people of the country. Classical dancers, though, still continued to represent the nation in the early 1970s, as the Republic harnessed the aesthetic, spiritual and political potency of the art to stake a claim to legitimacy. ${ }^{4}$ The communist Khmer Rouge, once in power in 1975, put an end to all practice and performance of this art, finding its association with monarchy and other former rulers to be at odds with their project of reshaping the populace to demonstrate loyalty only to the new regime. As soon as the Khmer Rouge were defeated in 1979, surviving dancers and musicians, in the absence of an estimated $80 \%$ of their colleagues who had perished in under four years of Khmer Rouge rule, tried as best they could to recreate their traditional repertoires. Ceremonies in which dance and music are offered as a way to seek abundance and well-being were officially revived in 1991, however, when members of the royal family returned. But this form of dance had long been practiced outside the palace, too, in rural and urban schools, in provincial cultural centers, and even in some villages, so that its resonances, whether as entertainment or ritual, were felt throughout the country.

As a young girl in the 1950s, Voan Savay used to visit Cambodia's royal palace to watch the dancers: her great aunt's job was to read lyrics to the singers. Savay started to practice alongside the performing artists, and eventually was selected to join the royal ensemble. One of her signature dances was called Apsara, a piece in which the performers' costumes and gestures are modeled on the ancient temple bas-reliefs of

\footnotetext{
2 "Khmer" is both the name of the majority ethnic group and the language of Cambodia. In common English usage, "Khmer" and "Cambodian" are often interchangeable as adjectives.

${ }^{3}$ Since about the 14th century, Theravada Buddhism has been Cambodia's official faith. However, the forceful heritage of animist, Brahman/Hindu and Mahayana Buddhist spirituality remains present in the language and the art, including dance.

${ }^{4}$ The country's official name, in English, had been the Kingdom of Cambodia. Following the 1970 coup, it became the Khmer Republic. When the Khmer Rouge won the civil war in 1975, they renamed the country Democratic Kampuchea. The People's Republic of Kampuchea followed in 1979. The United Nations had a brief stint overseeing a transitional government (The State of Cambodia) before the country became a Kingdom again after UN-supervised elections in 1991.
} 
celestial dancers. In Hindu mythology, apsaras emerged from the churning of the sea of milk by gods and demons. And in one Cambodian origin story, it was through the union of an apsara (Mera) with a wise man (Kambu) that the Khmer lineage was born. Thus, the mother of the Khmer people is a dancer. Apsaras "are seen as precious repositories of Cambodia's past and as such, the guarantors of her future" (Phim and Thompson 1999: 2). And dance has been generally understood by Cambodians as "essential to the perpetuation of Cambodia as a cultural and political entity" (ibid.).

With ornate, multi-tiered crowns, elaborate neck pieces and shimmering brocade skirts wrapped around their waists and pleated down the front, the dancers who perform as apsaras bring their sisters in stone to life. This particular dance, Apsara, was choreographed under the guidance of the queen herself, Sisowath Kossamak Nearyrath. The queen's granddaughter, Princess Norodom Buppha Devi, was usually the central apsara, and star of this work, with Savay in a supporting role. Later, Savay often took the princess' place (Jerome Robbins Dance Division 2009).

Apsara was developed for the stage; it is not a ritual dance. Yet it still exudes a sense of the divine, as do many pieces choreographed for entertainment in the 20th and 21st centuries, through its

tension between earthly groundedness and ethereal lightness evinced in a strong vertical pull, weight low and centered, balanced by movement across a horizontal plane. Sustained physical energy, visible in flexed fingers and toes and measured gestural progression, combines with fluid and seemingly effortless executions of posture and travel through space to convey at once a sense of solidity and of delicacy (Phim and Thompson 1999: 35-36).

As they enter and exit the performance space, dancers in many pieces trace a figureeight pattern across the ground, acknowledging the curvilinear path of the naga, a sacred serpent who inhabits the earth and water. Some of their hand and arm gestures are said by dance teachers to represent the head and tail of that revered being as well. ${ }^{5}$ Classical dancers, then, embody the spirit of the earth, and are thought to be able to sacralize land through their performance. When Voan Savay became a resident of Site 2 displaced persons camp in the 1980s, as we'll explore below, she called forth the essence of the naga through dance in that no-man's land, in a sense reclaiming the camp as symbolically situated on Cambodian soil, and naming it as protected and connected to her cultural heritage. She and her student dancers were thus re-grounding and retethering themselves, creating community, beauty and continuity in the midst of chaos, disruption, and danger. They were also making a statement about the/their future: In a protracted situation of exile, they nonetheless forged symbolic and embodied connections with history so as to imagine (and thus prepare for) a meaningful future, nurtured by cultural continuity.

\footnotetext{
${ }^{5}$ Soeur Ketya (1989) produced a detailed study of classical dance gestures.
} 


\section{Studying Displacement}

The more than a quarter of a million Cambodians in camps on the Thai side of the Cambodia-Thailand border in the late 20th century are referred to, in Khmer, as chun pies khluon. This translates into English as "refugees," but means, literally, "those who are escaping” or people on the run. Existing between a then-recent past of devastating loss and a future as yet unknown, they remained in an unsettled situation of layered precarity for more than a decade with many of the camps along that border located in an active war zone.

I conducted research in Site 2 displaced persons camp in 1989, as a student pursuing a PhD in cultural anthropology. ${ }^{6}$ Along with the directors of the "Fine Arts Service" in Site 2's Ampil sub-camp - Meas Van Roeun and Voan Savay (the one renowned for performing the role of an apsara) - I established a dance and music documentation project. ${ }^{7}$ Living in a nearby Thai town, and driving into the camp daily, I observed and filmed or photographed training, rehearsals and performances, as well as other aspects of life: people standing in line for hours for rations, or waiting behind others for a chance to fill a bucket with clean water that had just been trucked in by the United Nations and poured into storage tanks; and teenagers sweeping the packed-dirt floors of their small homes before trudging through mud in the rainy season as they made their way to a classroom. Using the equipment I provided, performing artists in the camp documented activities as well. I worked with them on this project for six months, while those I became closest to had already been in Site 2 since its creation in 1985, and had been in other camps along that border for much longer. Indeed, most artists (dance, music and theater students and teachers) with whom I worked lived in that war zone for ten or more years. The camp inhabitants were repatriated to Cambodia in 1992 and 1993, after U.N.-brokered peace accords were signed by all warring Cambodian parties in 1991.

In 1990 I moved from Site 2 into Cambodia, to continue conducting research on dance and war, but now from inside the country. I was able to return to Site 2 once again, in 1991, for a brief visit. I've been back to Cambodia numerous times over the

\footnotetext{
${ }^{6}$ I employed ethnographic fieldwork methods, including observation of as many aspects of the dancers' and musicians' and their families' lives as possible, formal and informal interviews and conversations with residents of the camp (artists, their families and others, including administrators), and lessons in dance. Throughout my time there, I spoke exclusively in Khmer to all those from Cambodia with whom I engaged.

${ }^{7}$ The Thai government didn't approve visas for research in the camps at that time, so I took a leave of absence from my graduate studies and got a job on the Thai-Cambodian border. I was employed by the International Rescue Committee (IRC), originally to work in an education program. Following the wishes of the artists I met in Site 2, and the awarding of external grant funds through the IRC, the dance documentation project was born. Funds supported, for example, a vehicle for transportation to and from the camp, camera equipment, videotapes and film, and shelves and storage cabinets in the Fine Arts Service of Site 2 office.
} 
ensuing years, for research, teaching, conferences and personal events, including weddings and funerals. I also lived there again, from 2008-2010, to help establish another research effort: I taught documentation skills, including interviewing, to dancers of the post-genocide generation, and worked on a book project with artists in the country about classical dance rituals. Over the decades, I've kept in touch with a number of the dancers and musicians who were repatriated to Cambodia, including Voan Savay. In 2020, Savay had gone to France and couldn't return to Cambodia because of the COVID19 pandemic. In early 2021, we spoke three times via Skype, Savay still in France and I in the United States, about her reflections on her life and art in the camp, and what she brought into being there. She reminisced about why it was so important to her to fashion beauty in the midst of horror, and how, through written and video documentation, she had wanted to create evidence of something that might or might not be there the next day, as they were always ready to be, once again, “on the run.”

This essay, while drawing on my initial fieldnotes, dissertation (Shapiro 1994), and other publications (Shapiro-Phim 2002; 2008), focuses on those more recent conversations, highlighting Voan Savay's - and Cambodian dance's - agency, that is, the capacity of the artist and of the art to make constructive things happen amidst the confines and possibilities of existence in a camp. Agency, involving a layered rendezvous and interaction with power structures, "is the capability of individual or collective actors to do something in the social realm .... Agents reflexively perceive their own capability of undertaking social action with an understanding of how power operates. ... Power is the capability to make action occur" (Page and Petray 2016: 89). Engagement with classical dance contributed to Savay's and other camp residents' imagining of possibilities beyond existing power structures. They were developing what peacebuilding scholar and practitioner John Paul Lederach calls the moral imagination, which is the capacity to both acknowledge current real-world discontents and dangers, and be open to the prospects of something much different, and much better. The moral imagination, according to Lederach, "requires the capacity to imagine ourselves in a web of relationships that includes our enemies; the ability to sustain a paradoxical curiosity that embraces complexity without reliance on dualistic polarity; the fundamental belief in and pursuit of the creative act; and the acceptance of the inherent risk of stepping into the mystery of the unknown that lies beyond the far too familiar landscape of violence" (2005: 5). Following the journeys of this one dancer in particular, this essay also notes the act of documenting dance as part of the generation of a moral imagination in circumstances in which, though almost everything had already been unmoored, there remained a strong likelihood that further losses would be suffered. Passing on cultural knowledge, both through bodies and in what Savay had hoped would be archival written and videotaped materials, planted seeds of aspirations for the future when, in fact, no end had been in sight to this life of precarity. 


\section{Life and Liminality}

With the exception of those born in refugee camps, every refugee used to have a life... a thousand little anchors once moored you to the world. Becoming a refugee means watching as those anchors are severed, one by one, until at last you're floating outside of society, an untethered phantom in need of a new life.

- Lev Golinkin (2018: 68), refugee from the Soviet Ukraine

The 1951 United Nations Convention on Refugees and the follow-up 1967 Protocol established a universal legal definition of refugees as those who have fled their own country and are unable to return because of a well-founded fear of persecution. In practice, countries of first asylum determine who is granted refugee status. Once someone gains official recognition as a refugee, certain protections are supposed to be afforded, including that against involuntary repatriation. However, referring to post-World War II refugees, Hannah Arendt states that "[i]nnocence, in the sense of complete lack of responsibility, was the mark of [the refugees'] rightlessness as it was the seal of their loss of political status. ... [T] he loss of a polity itself expels [them] from humanity" (1973: $295,297)$. The denial of one's humanity, and one's dignity, weighs heavily on individuals and communities experiencing such displacement.

Scholars of refugee situations have long invoked Victor Turner's concept of "liminality" in studies of life in camps (see, for example, Conquergood 1988 and Bousquet 1987). Turner (1967) identified liminal periods within rites of transition, extended moments when those experiencing a change in socio-cultural status are separated from their immediate past before eventually being admitted into their new roles within a given community. While undergoing these transitions, individuals are in an ambiguous position: they "pass[] through a cultural realm that has few or none of the attributes of the past or coming state" (Turner 1969: 94). But whereas uncertainty and a separation from familiar order into chaos or the unknown denote the initial experience of both initiates in a rite of passage and people who have fled across national borders, there are stark differences as well. In a rite of passage, people are guided through their transition by experienced elders. Refugees, people on the run, fend for themselves. Though they may have hopes, they do not know where (or to what status) they are heading. Considering the plight of Tibetan refugees, Margaret Nowak points out that "neither the de facto leaders of the community nor the inexperienced youth can be confident that ... reintegration [into the community, i.e. their homeland] will in fact occur" (1984: 45). They cannot know beforehand what lies at the end of this transitional experience, nor how long that transition will be.

Studies by Alexander Aleinikoff and Leah Zamore (2019) and Serena Parekh (2020) make formidable cases for revisiting and revamping international protocols for dealing with this crisis of long-term displacement and its attendant misfortunes and ills. Aleinikoff and Zamore outline the "conceptual innovation and concerted political action" (2019: 6) that will be necessary to counter the lack of rights of the stateless, and afford them opportunities to change their circumstances. And Parekh emphasizes the moral 
obligation, especially of those of us who are citizens of wealthier democracies, and who "contribute to and benefit from a global system that has the effect of preventing refugees from gaining refuge," (2020: 11) to confront "the political structures that unjustly prevent refugees from accessing the minimum conditions of human dignity” (ibid.: 8) These minimum conditions include adequate housing, food and medical care, access to elementary education, and safety. I would add the right and the wherewithal to participate in the cultural life of one's community, and to be gainfully employed - to not be dependent on aid agencies or other handouts. Parekh, indeed, shares that displaced individuals, especially those in camps, have articulated a desire for the ability to be selfsufficient while living in a place that denies both autonomy and hopes for a future (ibid.: 19). It is these kinds of harm she implores us to recognize, and to address.

The Thai government, having signed neither the United Nations Convention on Refugees nor the Protocol, formulated its own means of determining the status of those fleeing Cambodia. The border camps, thus, initially housed people the Thais called "illegal immigrants," or "displaced persons" as opposed to "refugees." Along that border, in the first year of the massive influx from Cambodia (1979), forced repatriations, sometimes over landmine-covered terrain, became international news. Even in the face of global condemnation, the practice was repeated.

The overall quality of life in Site 2, a camp created about five years later, was abysmal. A 1990 study found that,

Identifiable risk factors [in Site 2] known to contribute to the development of serious psychiatric illness include: Prior history of severe trauma, including starvation, torture, physical abuse and the death of relatives under the Khmer Rouge ...; Ongoing trauma in the camp secondary to lack of physical safety and protection, including war activities, domestic and community violence; Chronic malnutrition (50\% of Khmer children have stunting secondary to inadequate diets); Severe poverty (the majority of residents have access to minimum standards of food, clothing, shelter and other social amenities); Chronic unemployment (more than ten years) ...; Cultural, spiritual and moral deprivation (the latter prevents the development of adequate coping behavior especially for children and teenagers); Extensive demoralization secondary to prior and ongoing trauma, camp confinement and the almost non-existent possibility of safe repatriation in the near future; Large numbers of head injured and physically handicapped individuals; Epidemic of domestic violence and the sexual abuse of women and children (Mollica 1990: 134-135).

Engagement with the arts in Cambodian displaced persons camps was one means of subverting some aspects of such harm. It contributed to the affirmation of human dignity - of people's humanity - in those often-inhumane settings. Processes that restore and affirm human dignity are necessary in countering many of the impacts of displacement, as they lay the groundwork for the bolstering of people's agency, and for mean-

\footnotetext{
${ }^{8}$ In this essay, I equate much about refugee existence in camps with that of displaced persons (those without official refugee status) in camps.
} 
ingful connection or reconnection with self, culture and community. Through engagement with dance, people in Site 2 claimed some visibility and agency in a space where so much was proscribed. They also envisaged and encouraged a future of constructive possibility.

\section{Arts, Human Rights and Agency}

In 2020, UNESCO (the United Nations Educational, Scientific and Cultural Organization) inaugurated its Art Lab for Human Rights and Dialogue, a "laboratory of artistic interventions, which highlights the social role of artists in processes of memory and reconciliation and hence, in promoting human rights, dignity and artistic freedom," with a mandate to look at communities experiencing certain kinds of precarity, including displacement. Ultimately, the project aims to contribute to the promotion of human rights in circumstances of extreme vulnerability by addressing underlying injustices through arts and other aspects of cultural expression. Pointing to refugees in camps as an example, the Art Lab initiative acknowledges that

[t]oday when a person sets foot in a refugee camp in Africa, it is estimated that they will stay there for 17 years of their life. Providing shelter and food is not enough ... Processes involving artistic creativity can contribute to reconciliation, the restauration of human dignity, and the building of peaceful societies (UNESCO n.d.).

It is my contention that more than 30 years earlier, Voan Savay and her fellow artists were doing just that - contributing to the restoration of human dignity, staking a claim to mattering when stateless, and enacting peaceful resistance to the surrounding bloodshed and restrictions. In some ways, Savay and her colleagues and students were autonomous, re-creating valued aspects of their traditional cultural lives in Site 2, separated from Thai villages by barbed wire and armed guards, and from Cambodia by landmines and clashing armies. These particular displaced Cambodians, enveloped in a baneful power structure in a camp on Thai soil, thus asserted some agency. Although, as ethnomusicologist Ricardo Trimillos writes about minority populations and their music and dance practices, "[that agency] may not be satisfactory [nor] sufficient" (2021: 17), given limitations imposed on them, and the dangers all around. Nonetheless, just as historian Jana Lipman states about Vietnamese refugees in the 1980s, many Cambodians "were active players within the camps ... navigating camp bureaucracies" (2020: 11), and creating a way to practice and teach what they value. The efforts and choices of the artists in those surroundings are particularly consequential examples.

Dance and music in displaced persons' or refugee camps, as well as dancers and musicians, have been the subject of some scholarly inquiry elsewhere in Southeast Asia and beyond. Adelaida Reyes (1999) focused on the specifics of traumatic displacement among Vietnamese in camps and in the diaspora, noting that "[a]s part of expressive culture, music is a mirror that migration studies have yet to hold up to the refugee ex- 
perience," and, looking at her own field, "forced migration is a key that ethnomusicology has yet to turn to gain entry into another world that music inhabits" (3). In "Transit Migration: An Unnoticed Area in Ethnomusicology,” Evrim Hikmet Öğüt (2015) also laments the lack of ethnomusicological attention to the transit phase of displacement or migration. "As might be expected," Öğüt notes, "the interest of ethnomusicologists lies mainly in the musical production of settled migrant communities in various countries, usually the musical products of second and third generation migrants" (ibid.: 270). In writing about Chaldean-Iraqi migrants who entered Turkey in order to apply to the United Nations for formal refugee status so they could resettle elsewhere, Ögüt elucidates the ways in which

[t]ransit migration transcends the dichotomy that dominates the theoretical framework of migration studies between the country of origin and the destination point, as seen in migration theory based on pull-push factors. Instead, transit migration adds a third component: the transit phase/land. The best word to describe the essence of this transit phase as the core of this type of migration can be "uncertainty," both in an economic and a psychological sense. The uncertainty felt today discourages migrants from creating permanent relationships with and developing expectations of the circumstances that surround them. Rather, these expectations and hopes are postponed .... In this sense, the theoretical framework for migration in the ethnomusicology literature, which deals with settled communities, provides very limited insight (ibid.: 273).

Dance scholar Nicholas Rowe (2008) spent years living and dancing with Palestinian refugees in Ramallah, where movement and activities can be restricted and violence arbitrary, similar in ways to the situation of Site 2. He probes the tension between the artists' freedom and creativity in the studio, and the physical danger they face going to and from practice sessions. At Al Rowwad Cultural Theatre Training Center in the Occupied Palestinian Territories, in a separate enquiry, participants proclaim what they do - "cultural and arts activities whereby young people can resist occupation without being drawn into life-threatening confrontations with the Israeli army" - as "Beautiful Resistance" (Thompson, Hughes and Balfour 2009: 26-27). That might be an apt designation for the endeavors of artists in Site 2 as well.

Cambodians in Site 2, and all along the Thai-Cambodian border were, in fact, associated with the "resistance army," the fighting force made up of troops loyal to all previous Cambodian regimes: royalists (who lost power in 1970), Republicans (ousted in 1975) and the Khmer Rouge (defeated in 1979), trying to retake Cambodia from the Vietnamese-backed regime then ruling the country. ${ }^{9}$ But even within that political and military context, the dancers and musicians were bringing into being an aesthetic and

\footnotetext{
${ }^{9}$ The United States was implicated in this ongoing conflict and in the maneuvering and violence that gave rise to the Khmer Rouge in the first place. See Chandler (2008) for an examination of this complex history. My research and work in Site 2 and in Cambodia were, in part, a response to that history. As a U.S. citizen, I felt compelled to acknowledge my country's responsibility, and take some action to understand and counter the destruction.
} 
spiritual potency that transcended the surrounding reality, not only as momentary escape (though that can be powerful in its own right), but also as fortification against dehumanization. Under the guidance of dancer Voan Savay, on foreign land, with limited rights, and vulnerable to unremitting violence, they blossomed as Cambodian artists. Their "resistance" involved creating and experiencing beauty - actions that take you "beyond your own body and draw[] you into a concern for others" (Thompson, Hughes and Balfour 2009: 31). Site 2 was an institution, akin to a prison, "designed to control activity and access" (Ross 2008: 272) to an outside world. It also, not necessarily by design, but by the way it was experienced, ultimately controlled access for many "to the imaginative and affective world within” (ibid.). In the camp, the dancers, however, took control of the imagination of their future. Both the art-making and the documentation of these endeavors reinforced the notion that a future different from their current lived experience was possible, as the written notes and recordings were meant to be useful to coming generations.

\section{Leaving Home/Finding Camps}

The poem, "Home," by Warsan Shire, includes the following lines: "No one would leave home unless home chased you, fire under feet, hot blood in your belly . . . No one leaves home until home is a damp voice in your ear saying leave, run now, I don't know what I've become" (2019: 29). This poem was the first thing to greet visitors to a 2019 exhibition at the Institute of Contemporary Arts/Boston (USA), When Home Won't Let You Stay. The artists and artworks selected, the curators share, explore "displacement and regrounding," and give us a chance to ponder the fact that

[m]any provisional or temporary sites directly shape the contours of migration: borders, refugee camps, detention centers, and other infrastructure meant to control movement .... Refugee camps and centers are often constructed as temporary settlements for people forced to flee, but some have become extensive permanent cities, housing hundreds of thousands of people for decades .... The power that [borders and camps] wield hinges entirely on the mobility and freedom afforded - or not - by one's status (Erickson and Respini 2019: 24).

A country with a population of just over seven million in 1975, Cambodia lost approximately two million of its inhabitants in just under four years of Khmer Rouge rule from April 1975 to January 1979. Starvation, no access to effective medicine, overwork, torture and execution led directly to the deaths of more than a quarter of the populace. The Khmer Rouge's communist revolutionary vision for the country involved purging the nation of intellectuals and those associated with former regimes; they forced city dwellers into the countryside to participate in collective agricultural schemes that, more often than not, resulted in no bounty for those who had labored in the fields. Most Cambodians stayed in the country when this nightmare (during which children were separated from their parents and often made to spy on them; women and men were 
paired in forced marriages, constituting, in fact, institutionalized rape; and almost everyone lost their homes and livelihoods, not to mention loved ones), came to an end in early $1979 .{ }^{10}$ But hundreds of thousands, finding that "home would not let them stay," hazarded a journey out of that shattered nation.

Cambodians flooded west towards Thailand, many sickly and starving, as soon as Cambodia itself had been liberated from the rule of the Khmer Rouge. Thousands were fleeing famine that resulted from the Khmer Rouge's disastrous agricultural practices that had been in place since they had declared victory in a civil war in 1975; others were trying to find their way out of a war then being waged between the retreating Khmer Rouge and the also-communist Vietnamese-led regime that had ousted them. Still others were forced west, to the border with Thailand, by Khmer Rouge soldiers, who rounded up whatever populations under their control they could. The dire circumstances in Cambodia - lack of infrastructure, markets, schools, food, communications systems and basic governance - were exacerbated by a U.S.-led embargo on aid as punishment of the Vietnamese (the enemy of the U.S. at the time) who had freed Cambodia of the Khmer Rouge, and remained. But leaving home meant traipsing through mine-strewn forests. ${ }^{11}$ It meant the potential of being mugged by robbers who reached into women's (and girls') bodies to see if they had hidden gems that they or their families would later trade for sustenance. It involved the risk of being stopped and forced back by Thai soldiers, as policies shifted (Chantavanich and Rabe 1990). Indeed, for many, it meant staying in makeshift camps on the Cambodian side of the border, well within reach of falling artillery shells.

Cambodians were running to find a place in which they could feed themselves or their children, or go to university, or reunite with family members from whom they'd been separated. They were running to find a place free from restrictions on spiritual practice, and free from violent conflict. Ending up on the Thai-Cambodian border, though, had its own (unforeseen) devastating consequences. "It is common to think of borders as pathways for movement," writes Aruna D’Souza (2019: 165). "But borders are more commonly sites of stoppage and stasis and containment and incarceration" (ibid.).

While it's true that there was some fluidity of travel from one country to the other (black market trading was one example), the flux was mainly in response to military aggression. As the war for Cambodia intensified, denizens of this no-man's land were buffeted in one direction and then the other.

Dancers Voan Savay and Meas Van Roeun, each having survived the Khmer Rouge regime, had been in camps on the Cambodian side of the border since 1981. Savay, a

\footnotetext{
${ }^{10}$ Eve Zucker (2020) offers a poignant introduction to the immediate aftermath of the Khmer Rouge regime.

${ }^{11}$ The Halo Trust (n.d.) reports that "[l]andmines laid during the ousting of the Khmer Rouge in 1979 and throughout the 80s and 90s have had a devastating impact on the people of Cambodia. Over 64,000 casualties and more than 25,000 amputees have been recorded since 1979.”
} 
former principal dancer with the royal troupe, was a star of the "female" role in classical dance. Her husband, Van Roeun, a folk dancer, was a graduate of the University of Fine Arts. They fled Cambodia because of fears that the Khmer Rouge would return to power. "We were young and newly married. We were afraid of the ongoing war, and had heard about people escaping and then resettling in a third, peaceful country," recalled Savay. ${ }^{12}$ Now trapped in encampments run by different warlords or, later, affiliated with one of the political/military factions fighting to re-take Cambodia, Savay and Van Roeun initially established a small arts program for children, seeing that the young people had no structured activities, and recognizing "that this is where our knowledge was. It became our responsibility to impart it to the younger generation. And then, eventually, we didn't want to leave, except to go home again when it was safe.” To do this, though, they had to make a case to the military units controlling their camp. When resources were scarce, when the violence was unpredictable, why dedicate time, effort and space to music and to dance? "I don't know," said Savay. "We didn't think about it when we first ran away. But we saw that these children needed something to connect them with their homeland, something more than war. And they needed joy.”

They went around the encampment recruiting children, and musicians - anyone who had played in a village or city ensemble anywhere in the country. Cambodia has rich and varied musical traditions, with discrete ensembles for folk dances and various folk theater forms, weddings, funerals, Buddhist rituals, and so on. The musicians with whom they connected at first made their own instruments from found materials. Whereas inside Cambodia, regional styles would have set some musicians apart from others, in this encampment, they made do. They found ways to hear and respond to one another, as elaboration of instrumentation is critical. And Savay and Van Roeun started to teach. The musicians accompanied folk dances. But for the classical dances they used tape cassettes Savay had brought with her from Phnom Penh. The music attracted passers-by. "Even some soldiers left their ranks and decided to become dancers instead. They loved it that much," Savay remembered. In the confines of the camp, when even just outside was a source of almost-certain danger, Savay and Van Roeun nurtured focus amidst chaos, beauty within surrounding indignities, and purpose related to home - in both spiritual/symbolic and very tactile senses.

It wasn't until all-out war enveloped the border that Savay herself realized the extent of the impact she and her art were having on the children with whom she had been working, and their families. In 1984-1985, over several months, Savay, Van Roeun, and at least 60 of their dance students were on the run. ${ }^{13}$ The sounds of artillery fire had become familiar. Usually, however, there was some let-up. When there was not only no

\footnotetext{
${ }^{12}$ Voan Savay, pers. comm., 26 February and 13 and 14 June 2021. All quotations of Voan Savay's words are from these interviews I conducted by Skype, unless noted otherwise. We spoke in Khmer. I read versions of this essay to her, with the help of Cambodian dancer and native Khmer speaker Thavro Phim, to check for errors or changes Savay wanted.

${ }^{13}$ They had been on the run before, all from inside Cambodia to the border. And from earlier camps to this one. But now they were on the run as a group.
} 
break in the booms, but shells were landing all around them, camp residents did whatever they could to seek shelter. "Whenever we heard bombs, we'd jump into the trenches. When they stopped, we'd pick up whatever we had been doing. When the big fighting came, and didn't stop," Savay said, she and Van Roeun rushed to load up the cart they had for transporting musical instruments from their hut to the practice area. They tossed some clothes, cooking pots and bags of rice onto it, forsaking the instruments and any dance costumes they had managed to fashion. "The most important thing was the rice and the pots," Savay recalled. "I knew I'd have some children to look after,” referring to her dance students. "Nothing else was important.” Savay:

When the whole camp ran, I ran. And the little kids - six, seven years old - they ran with us. We told them to go run with their parents: "We're scared you'll lose your parents," we said. All those kids answered, "Our parents told us to run with you. Whatever happens, don't lose Neak Kru [honorific term for female teacher].” That stayed with me my whole life. They believed that I loved their children, too, as they did. They trusted the lives of their daughters and sons to me. Because Neak Kru had the wherewithal to raise them and give them a good future. I didn't have money, but I had my art. I'm not sure exactly what the parents thought, but I know that when those kids made mistakes or misbehaved, the parents would take the kids to me to discipline them. I don't know why. "Be careful - I'll take you to Neak Kru," they'd warn their children. Maybe the parents knew the students didn't want to disappoint their teacher. I wasn't preparing them for resettlement [in another country]. That would have been a reason to follow me. At the border there were some who wanted to go to a third country. And there were others like me who wanted to repatriate when it was possible. And these children and their families stuck with me.

I'm not sure what happened to all the musicians. We lost everything. And almost everyone.

It was so difficult, those many months of living and running. I wondered why I was still alive. We'd put a tarp over the branches of a tree, hang some hammocks and try to sleep. Then we'd be awakened by artillery shells and set off again. The fighting was so severe that the Thai military let some of us run across the border. It then got so intense that we couldn't return to Cambodia. They gathered us into a huge camp they called Site 2.

In the chaos and terror, "approximately 200,000 more Cambodian displaced persons evacuated to Thai border camps” (Chantavanich and Rabe 1990: 66). Site 2 housed upwards of 140,000 residents from a number of former camps, all now affiliated with the Khmer People's National Liberation Front, the faction of supporters of the former Khmer Republic regime, fighting to drive out the Vietnamese-backed People's Republic of Kampuchea. Savay and Van Roeun were in Ampil sub-camp. Remarkably, there, Savay reunited with a former palace musician, Proeung Pruon, who had accompanied her when she danced in the 1960s and early 1970s. He and other accomplished artists 
formed a pin peat ensemble ${ }^{14}$ in Ampil sub-camp of Site 2, specifically for the classical dances.

\section{Site 2}

Keeping people in a refugee camp is punishing people who have committed no crime except trying to save their own lives and the lives of their loved ones. The refugee camp belongs to the same inhuman family as the internment camp, the concentration camp, the death camp. The camp is the place where we keep those who we do not see as fully being human, and if we do not actively seek their death in most cases, we also often do not actively seek to restore many of them to the life that they had before, the life we have ourselves (Nguyen 2018: 18). ${ }^{15}$

Site 2, even though it was on Thai soil, was not immune from spill-over from the war. Trenches were built for protection from artillery shells, and used as needed. It was surrounded by barbed wire fencing, and patrolled by Thai guards. Some camp residents who snuck out to scavenge for firewood, for example, were shot. Others ventured further and stepped on land mines. Savay:

Throughout all those years, I suffered. First, we were in a war zone. Second, we never ate anything we wanted to or longed for. We ate whatever rations they gave us, just to survive. As an artist, and a famous one, it would have been best for me to have comfort and good health. I might have expected it. Being dancers, we have to take care of our bodies. But, at that time, I never thought of myself. If I survived in that war zone, I still might have lost a limb, but I never thought about that.

When I arrived in Site 2 in 1989, the Vietnamese-backed Cambodian forces inside Cambodia had not yet retreated from the border. It was still an active war zone. And, even though Site 2 was ostensibly a civilian camp, its affiliation with one of the fighting factions meant the dance troupes in that enclosure were, in a way, legitimizing the leadership of that political/military entity. Site B, the camp affiliated with the royalists, for example, had its own troupe. ${ }^{16}$ While the political/military associations weighed heavily, I still found that the dancers and their families were concentrating on the meaning

\footnotetext{
${ }^{14}$ The pin peat is a predominantly percussion orchestra which generally includes a sralai (quadruple-reed oboe-like instrument); one high- and one low-pitched roneat (xylophone with wooden or bamboo keys) plus, sometimes, a roneat with steel keys; kong (circle of knobbed gongs), sometimes both a high- and a low-pitched gong circle; sampho (double-headed barrel drum mounted horizontally on a stand and played with hands); skor thom (large pair of barrel drums sounded with mallets); and handheld brass cymbals (chheung). See the PhD dissertation on this particular ensemble by Cambodian ethnomusicologist Sam-Ang Sam (1988).

${ }^{15}$ Zaye Tete, a Liberian singer and dancer, speaking about her experience as a refugee in the Ivory Coast where she created a youth performing arts troupe, noted during an interview, "I don't pray for anyone to be a refugee. You're in the next man's country. You have no freedom” (Shapiro-Phim 2018).

${ }^{16}$ Later, when peace was being negotiated, even Site 8, a Khmer Rouge camp, established a dance troupe. The Khmer Rouge are the ones who had forbidden this kind of cultural expression while
} 
of the danced stories, and the exquisite and demanding technique. The children wanted to be excellent. They told me as much, and spoke to each other about this, too. Their parents wanted them to be strong [khlang] and beautiful [sa-at], they would say, to keep their cultural heritage alive, and to bring peace to Cambodia. ${ }^{17}$

The characters in the danced stories have magical powers: they fly through the heavens; they defeat evil. Acrobatic monkeys, stately princes, graceful princesses and menacing (yet still highly controlled) ogres enact tales of loyalty and love, and commitment to kingdom and family. In Site 2, they defied the fences and the armed guards, creating an elsewhere beyond that parched land so vulnerable to attack. They were both grounded - having re-made the earth beneath their bare feet into Cambodian soil through movement that embodies a sacred serpent - and existing above the confines of camp and war as other-worldly beings. Savay:

In that sad place, the thing that gave me pleasure was that I could bring all the kids some orphans, some with parents but still so poor - I was able to gather them to create an arts troupe on the border. I wasn't happy, but it was wonderful to see them grow as Khmer artists. They were beautiful. Ultimately, I'm proud that we created a place with a school. The students studied technique in the morning and academics in the afternoon, just like a school in Cambodia. We taught them the history and meaning of the arts they were studying. They knew their importance. The tevoda [heavenly/divine beings] have eyes. They saw what we were doing, and were pleased.

With controlled grace, and accompanied by xylophones, gong circles, drums, an oboelike instrument and a chorus - sometimes of dancers themselves - young people reclaimed a cultural heritage passed down by their teacher, but denied and violated by their surrounding reality, and almost wiped out during the immediate past.

Savay and Van Roeun oversaw all of this of their own accord in the first two border camps in which they had lived, and with more help in Site 2. Just as Thompson, Hughes and Balfour note about "grassroots initiatives [in the Occupied Palestinian Territories] started by practitioners without or with very minimal support from external agencies" (2009: 27), performing arts efforts on the Thai-Cambodian border weren't the priority of aid agencies. It might be assumed that, as Thompson, Hughes and Balfour continue, "individuals and groups in areas of continuing war cease to develop new work or conduct any arts-based activities" (ibid.), but that is a false assumption. "[T]he acts of theatre and performance undertaken in extreme situations . . . emphasize that living in war conditions engenders multiple and complex responses. The absence of international organizations or critics is more often the cause of the invisibility of this practice than its actual non-occurrence" (ibid.). ${ }^{18}$ Savay:

they were in power, allowing only a formulaic repertoire extolling their revolution. See ShapiroPhim (2002) for an exploration of dance and music during the years of Khmer Rouge rule.

${ }^{17}$ Parents of dancers inside Cambodia told me the same thing in 1990, explaining that classical dance contributed to the country's well-being.

${ }^{18}$ The existence and complex, poignant meanings of the arts in agonizing circumstances of confinement, beyond refugee camps, have been documented in books, movies and exhibitions. See, 
Only in Site 2 were we finally able to have a full pin peat ensemble. When guests came to watch us, sometimes they'd give us a donation in Thai baht. [There was no money given out or in official use in Site 2.] We didn't ask for money, but we saved those donations and used them to buy instruments through traders who snuck back and forth across the border. Or, we would ask [the non-governmental agency] COERR [Catholic Office for Emergency Relief and Refugees] to buy instruments for us in Thailand. They got special permission to take us out of camp to go order the instruments. With a full orchestra and accomplished dancers, we performed rituals to ask for guidance and blessings, and also presented dances to thousands of our fellow refugees. They would gather around [the outdoor stage], standing in the sun, and watch and smile and clap. Because Lok Kru [honorific for male teacher] Van Roeun and I demanded a high level of technique, the UN asked us to guide all the performing arts programs that Cambodians had established in other sub-camps of Site 2. UNBRO [the United Nations Border Relief Operation] helped us with additional rice and canned fish for all the students. COERR helped with costumes.

Also of her own accord, Savay started to document the dance. She began to notate, in narrative form, gestures and movements for particular characters in the classical repertoire. Before the war and revolution, no such documentation had been undertaken in Cambodia. And, as most of the accomplished performing artists had perished during the years of Khmer Rouge rule, this meant that the cultural knowledge that rested in the memories and bodies of survivors was precious. She counted herself among them. Singing to accompany herself, she'd jot down lyrics. Moving first as a female character, she'd record on paper what she had just enacted by describing arm placement, or the tilt of the head, and so on. Then, kinesthetically recalling the choreography of the male character, opposite whom she would have rehearsed and performed in the palace in the old days, she embodied that prince or god. She recorded that character's movements as well. As she did all of this, her students were watching and listening. Some of them helped to model movement passages if they could execute them well enough. They were learning the material, and, at the same time, internalizing it. The documentation was inscribed in their bodies, as it had been in Savay's, as well as on paper.

When I asked performing artists in Site 2 what their priorities would be if we were to get funding for a project, artistic directors from each of the sub-camps met and took a vote. Unanimously they put forth a proposal for a documentation initiative to build on what Savay had started. They also wanted to videotape what they were doing in the camp. They chose to start with classical dance. Why classical dance? I asked. "Because it is the soul of our nation, of Cambodia," they answered.

for example, Johnson (2012) about music and dance among the enslaved in Haiti and elsewhere, Doug Shultz's (2013) documentary about a classical music conductor in Terezin Nazi concentration camp, and "The Art of Gaman" (Smithsonian American Art Museum n.d.) about the experiences of Japanese Americans interned by the U.S. during the Second World War, which toured museums in 2010 and 2011. 
Back in 1989, Savay told me what she had in mind: "With these tapes, Cambodians will know what we did. We didn't just sit here in the forest and wait. We remembered our [traditional] stories and made new ones. We preserved our culture and prepared the next generation of artists. We don't know when we'll be able to go back home, but, when we do, these tapes will help others remember and teach, too." ${ }^{19}$ It was the moral imagination at work.

It was, in part, a race against time, and, in part, an emplacement, the opposite of running again and again. Even without being home, still being unsettled with an unknown trajectory for return, Savay built a space of creation in terms of a material archive, alongside the human one. If the running didn't save her next time, if that limb was blown off, the world would still have written notes and recorded images declaring a solid footing on this earth, and in history.

Savay mused about where her strength and dignity had come from during all those years.

I was a refugee, with no rights. Anyone could do whatever they wanted to me, and nobody would know. But I never lowered my head in front of anyone. And Thais and others [in authority] honored my wishes, even when they wanted something else. ${ }^{20}$ As I think of it now, why was I tough, and not afraid to argue with them? There was something inside me that wouldn't let anyone oppress me. Maybe it's because I had my culture, and my heritage. I knew I had to lead, and to help the younger generation understand that this [culture] is theirs, too, and it is precious.

She was active in her agency.

Thousands of their fellow camp inhabitants watched performances of classical dances and dance dramas as well as folk dances, the latter often playful and, sometimes, flirtatious. ${ }^{21}$ And hundreds would crowd around the training hall to look in on classes and rehearsals. It might have been a diversion from the monotony of camp life, so dependent as it was on waiting for what was provided by others. But engaging with these arts, as a performer, teacher, documentarian or audience member, was also, and even more so, a way to control at least part of one's narrative, and to stake a claim as being Cambodian when one was officially stateless. A way to imagine alternatives, new futures. A way to rehumanize oneself as part of a community with some sense of continuity in conditions of indignity, disruption and fear. A statement from the United Nations

\footnotetext{
${ }^{19}$ From fieldnotes. A similar documentation effort had been underway among dancers inside Cambodia. Savay had no communication with them back then, and was unaware of the project; I found out about it when I moved to Cambodia in 1990.

${ }^{20}$ Remarkably, Thai authorities and officials at the U.S. Embassy in Bangkok allowed 53 dancers, musicians and costumers from Site 2, under Savay and Van Roeun's direction, to go on a performance tour of the United States, after which they returned to the camp. A Thai official wanted to accompany them on the trip. Savay refused so that "everyone would understand this is a Cambodian dance troupe, no matter what country's land we were living on.” There's a long history of both shared aspects of culture, and animosity related to cultural heritage between Thais and Cambodians.

${ }^{21}$ Chap (1964) produced a study about folk dances throughout Cambodia.
} 
Office of the High Commission on Human Rights proclaims that "[h]umanity dignifies, restores and reimagines itself through creating, performing, preserving and revising its cultural and artistic life" (Bennoune 2018). For Savay and her dancers, engaging with the arts was a way to attempt to restore, store and share at least some cultural knowledge - through one's body and, externally, on paper or videotape - in service of the future of possibilities they imagined for themselves and their country. ${ }^{22}$

\section{References}

Aleinikoff, Alexander, and Leah Zamore. 2019. The Arc of Protection: Reforming the International Refugee Regime. Stanford: Stanford University Press.

Arendt, Hannah. [1951] 1973. The Origins of Totalitarianism. New York: Harcourt Brace Jovanovich.

Bennoune, Karima. 2018. "Statement by Ms. Karima Bennoune, Special Rapporteur in the field of cultural rights at the 37th Session of the Human Rights Council, 1 March 2018." United Nations Human Rights: Office of the High Commissioner (website). Accessed 27 February 2021. https://www.ohchr.org/EN/NewsEvents/ Pages/DisplayNews.aspx?NewsID=22908\&LangID=E

Bousquet, Gisele. 1987. "Living in a State of Limbo: A Case Study of Vietnamese Refugees in Hong Kong Camps.” In People in Upheaval, edited by Elizabeth Colson and Scott Morgan, 34-53. New York: Center for Migration Studies.

Chandler, David. 2008. A History of Cambodia. 4th ed. London: Routledge.

Chantavanich, S., and P. Rabe. 1990. "Thailand and the Indochinese Refugees: Fifteen Years of Compromise and Uncertainty." Southeast Asian Journal of Social Science 18(1): 66-80.

Chap Pin. 1964. Robam Procheaprey Khmer [Khmer Popular Dances]. Phnom Penh: Buddhist Institute.

Conquergood, Dwight. 1988. "Health Theatre in a Hmong Refugee Camp." The Drama Review 32(3): 174-208.

D’Souza, Aruna. 2019. “Waiting to Go.” In When Home Won't Let You Stay: Migration Through Contemporary Art, edited by Ruth Erickson and Eva Respini, 162-171. New Haven: Yale University Press.

Erickson, Ruth, and Eva Respini, eds. 2019. When Home Won't Let you Stay: Migration Through Contemporary Art. New Haven: Yale University Press.

Golinkin, Lev. 2018. "Guests of the Holy Roman Empress Maria Theresa." In The Displaced: Refugee Writers on Refugee Lives, edited by Viet Thanh Nguyen, 67-72. New York: Abrams Press.

\footnotetext{
${ }^{22}$ Just before Savay, Van Roeun, and their dancers and musicians were repatriated to Cambodia, there was a fire in their section of Site 2. All of the documentation materials, including the videotapes, were destroyed. I had shipped copies of the tapes to the U.S. when I left Site 2. They should all be in the Bophana Audiovisual Resource Center Archives in Phnom Penh, in digitized format, by the time this is published.
} 
The Halo Trust. n.d. “Cambodia.” The Halo Trust (website). Accessed 27 February 2021. https://www.halotrust.org/where-we-work/south-asia/cambodia/\#: :text= Landmines\%20laid\%20during\%20the\%20ousting,have\%20been\%20recorded $\% 20$ since $\% 201979$

Johnson, Sara E. 2012. The Fear of French Negroes: Transcolonial Collaboration in the Revolutionary Americas. Berkeley: University of California Press.

Lipman, Jana. 2020. In Camps: Vietnamese Refugees, Asylum Seekers, and Repatriates. Oakland: University of California Press.

Mollica, Richard. 1990. "Communities of Confinement: An International Plan for Relieving the Mental Health Crisis in the Thai-Khmer Border Camps," Southeast Asian Journal of Social Science 18(1): 132-152.

Nguyen, Viet Thanh. 2018. "Introduction.” In The Displaced: Refugee Writers on Refugee Lives, edited by Viet Thanh Nguyen, 11-22. New York: Abrams Press.

Nowak, Margaret. 1984. Tibetan Refugees. New Brunswick: Rutgers University Press.

Öğ̈t, Evrim Hikmet. 2015. “Transit Migration: An Unnoticed Area in Ethnomusicology.” Lidé města / Urban people 17(2): 269-282.

Page, Alexander, and Theresa Petray. 2016. "Agency and structural constraints: Indigenous peoples and the Australian settler-state in North Queensland.” Settler Colonial Studies 6(1): 88-98. https://doi.org/10.1080/2201473X.2014.993057

Parekh, Serena. 2020. No Refuge: Ethics and the Global Refugee Crisis. New York: Oxford University Press.

Phim, Toni, and Ashley Thompson. 1999. Dance in Cambodia. New York: Oxford University Press.

Reyes, Adelaida. 1999. Songs of the Caged; Songs of the Free: Music and the Vietnamese Refugee Experience. Philadelphia: Temple University Press.

Ross, Janice. 2008. "Doing Time: Dance in Prison.” In Dance, Human Rights and Social Justice: Dignity in Motion, edited by Naomi Jackson and Toni Shapiro-Phim, 270284. Lanham: Scarecrow Press.

Rowe, Nicholas. 2008. “Exposure and Concealment.” In Dance, Human Rights and Social Justice: Dignity in Motion, edited by Naomi Jackson and Toni Shapiro-Phim, 291295. Lanham: Scarecrow Press.

Sam, Sam-Ang. 1988. “The Pin Peat Ensemble: Its History, Music and Context.” Ph.D dissertation, Wesleyan University.

Shapiro, Toni. 1994. "Dance and the Spirit of Cambodia.” Ph.D dissertation, Cornell University.

Shapiro-Phim, Toni. 2002. "Dance, Music and the Nature of Terror in Democratic Kampuchea.” In Annihilating Difference: The Anthropology of Genocide, edited by Alexander Laban Hinton, 179-193. Berkeley: University of California Press.

- 2008. "Mediating Cambodian History, the Sacred, and the Earth,” In Dance, Human Rights and Social Justice: Dignity in Motion, edited by Naomi Jackson and Toni Shapiro-Phim, 304-322. Lanham: Scarecrow Press.

Shire, Warsan. 2019. “Home.” In When Home Won't Let You Stay: Migration Through Contemporary Art, edited by Ruth Erickson and Eva Respini, 28-29. New Haven: Yale University Press. 
Smithsonian American Art Museum. n.d. "The Art of Gaman: Arts and Crafts from the Japanese American Internment Camps, 1942-1946.” [Exhibition, 5 March 2010 30 January 2011.] Accessed August 12, 2021.

https://americanart.si.edu/exhibitions/gaman

Soeur Ketya. 1989. “Cholna Kayvikar Ning Nay Nei Robam Khmer” [Movement, Gesture, and Meaning of Khmer Dance]. Bachelor's Thesis, University of Phnom Penh.

Thompson, Ashley. 1993. “Oh Cambodia! Poems from the Border.” New Literary History 24(3): 519-544.

Thompson, James, Jenny Hughes and Michael Balfour. 2009. Performance in Place of War. London: Seagull Books.

Trimillos, Ricardo. 2021. “The Music of 'Minorities' as Lived Experience and Performed Identity: The Philippines' Sulu, America's Hawai'i, and Japan’s Okinawa.” In $\mathrm{Mu}$ sic and Marginalisation: Beyond the Minority-Majority Paradigm, edited by Ursula Hemetek, Inna Naroditskaya and Terada Yoshitaka, 13-27. Osaka: National Museum of Ethnology.

Turner, Victor. 1969. The Ritual Process. Ithaca, New York: Cornell University Press.

UNESCO. n.d. “Art Lab for Human Rights and Dialogue.” UNESCO (website). Accessed 20 July 2021. https://en.unesco.org/themes/learning-live-together/art-lab

UNHCR. 2020. “Protracted Refugee Situations Explained.” UNHCR (website), 28 January 2020. Accessed 20 July 2021. https://www.unrefugees.org/news/protracted -refugee-situations-explained/

UNHCR. 2021. "Live Blog 2021: This World Refugee Day, we are stronger together.” UNHCR (website), 20 June 2021. Accessed 20 July 2021. https://www.unhcr.org/ news/latest/2021/6/60ad1e2f4/live-blog-2021-world-refugee-day-stronger -together.html

U.S. Department of State. n.d. "Protracted Refugee Situations.” U.S. Department of State (website). Accessed 20 July 2021.

https://2009-2017.state.gov/j/prm/policyissues/issues/protracted/index.htm\#: : text=People\%20in\%20protracted\%20refugee \%20situations, situations $\% 20$ is $\% 20$ now $\% 2026 \% 20 y e a r s$

Zucker, Eve Monique. 2020. "In the Realms of Ritual and Enchantment: Imagination and Recovery in the Aftermath of the Khmer Rouge." In Coexistence in the Aftermath of Mass Violence, edited Eve Monique Zucker and Laura McGrew, 29-52. Ann Arbor: University of Michigan Press.

\section{Multimedia Sources}

Jerome Robbins Dance Division, The New York Public Library. 2009. "Interview with Voan Savay and Voeun Amrit.” New York Public Library Digital Collections. Filmed on 22 August 2009 in Phnom Penh, Cambodia. Digitized copy of a DVcam videocassette, 26:47. Accessed 27 February 2021.

https://digitalcollections.nypl.org/items/96f3f480-3451-0131-e736-3c075448cc4b

Ok, Prumsodun. 2017. “The Magic of Khmer Classical Dance.” Filmed April 2017 in Vancouver, Canada. TED video, 10:29. Accessed 27 February 2021. 
https://www.ted.com/talks/prumsodun ok the magic of khmer classical dance?language $=$ en $\# \mathrm{t}-31123$

Shapiro-Phim, Toni, director. 2018. Because of the War. Produced by the Philadelphia Folklore Project. Documentary film. http://www.becauseofthewar.org/

Shultz, Doug, director. 2013. Defiant Requiem. Produced by Partisan Pictures. Documentary film. https://www.defiantrequiem.org/film/faqs/

\section{Ethnographic Data}

Savay, Voan. Personal communication with author by Skype. 26 February and 13 and 14 June 2021.

\section{Author Biography}

Toni Shapiro-Phim, Professor of Creativity, Arts, and Social Transformation and Assistant Director of Peacebuilding and the Arts at Brandeis University (USA), received a PhD in cultural anthropology from Cornell University. Her applied and scholarly work focuses on displacement, war, genocide and gender violence, and the arts, with publications (and a documentary film) on arts and human rights, dance and transitional justice, and performance and community building. 